\title{
AHL Signals Induce Rubrifacine Production in a bruI Mutant of Brenneria rubrifaciens
}

\author{
Ali E. McClean, Breck A. Duerkop, E. Peter Greenberg, and Daniel A. Kluepfel
}

First and fourth authors: Crops Pathology and Genetics Research Unit, United States Department of Agriculture-Agricultural Research Service (USDA-ARS), 259 Hutchison Hall, Department of Plant Pathology, One Shields Avenue, University of California, Davis 95616; and second and third authors: Department of Microbiology, University of Washington School of Medicine, Seattle 98195-7242.

Current address of B. A. Duerkop: Department of Immunology, University of Texas Southwestern Medical Center, Dallas 75235.

Accepted for publication 20 October 2011.

\begin{abstract}
McClean, A. E., Duerkop, B. A., Greenberg, E. P., and Kluepfel, D. A. 2012. AHL signals induce rubrifacine production in a bruI mutant of Brenneria rubrifaciens. Phytopathology 102:195-203.

Several members of the bacterial genus Brenneria are pathogenic on different tree species. Cell-free extracts from the bacterial phytopathogens Brenneria rubrifaciens, B. salicis, and B. nigrifluens induced production of the red pigment rubrifacine in the B. rubrifaciens bruI insertional mutant $\mathrm{Br}-212$. Analysis of the bruI locus identified an adjacent open reading frame, designated $b r u \mathrm{R}$, with homology to luxR. High-performance liquid chromatography and mass spectrometry analysis of ethyl acetate extracts from wild-type B. rubrifaciens and Escherichia coli expressing the bruI gene identified two acyl homoserine lactone (AHL)

peaks, $\mathrm{N}$-(3-oxohexanoyl)-homoserine lactone (3OC6HSL) and $\mathrm{N}$ hexanoyl-homoserine lactone (C6HSL). Addition of synthetic 3OC6HSL and C6HSL at $10 \mu \mathrm{M}$ to the $b r u \mathrm{I}$ mutant, strain $\mathrm{Br}-212$, induced rubrifacine production and the ability to elicit a hypersensitive reaction (HR) in tobacco leaves. Synthetic C6HSL was less effective at inducing pigment production than $3 \mathrm{OC} 6 \mathrm{HSL}$ at $10 \mu \mathrm{M}$. The bruI mutant $\mathrm{Br}-212$ did not produce detectable AHLs, indicating that C6HSL and 3OC6HSL are the major AHLs produced by this species. The AHLs N-heptanoyl-DLhomoserine lactone (C7HSL), N-octanoyl-DL-homoserine lactone (C8HSL), and $\mathrm{N}$-(3-oxooctanoyl)-DL-homoserine lactone (3OC8HSL) also induced pigment production in $\mathrm{Br}-212$ and restored its ability to elicit an HR in tobacco, suggesting that cross-talk with other bacterial species may be possible.
\end{abstract}

Microorganisms sense other microorganisms in the environment using a variety of mechanisms. One of the best-studied chemical communication systems in bacteria is quorum sensing (QS), a type of intercellular communication which depends on the production of and response to low molecular weight inducers in a cell-density-dependent manner $(10,29)$. These signaling molecules are called autoinducers (AIs). They are classified into two groups: AI-1 molecules, used primarily for intraspecies communication, and AI-2 compounds, thought to be important for interspecies communication $(5,11,65)$.

The best-studied AI-1 molecules from many gram-negative bacteria are fatty acid derivatives (type I), whereas peptide derivatives (type II) are well defined for gram-positive bacteria. The type I system consists of three major parts, acyl homoserine lactone (AHL) signaling molecules, the synthases that produce the AHLs, and receptors that bind AHLs and alter gene expression $(28,68)$. QS was first described in the marine symbiont Vibrio fischeri $(22,24)$. LuxI, an acyl homoserine synthase, produces the AHLs $N$-(3-oxohexanoyl)-homoserine lactone (3OC6HSL) (major AHL) and N-hexanoyl-homoserine lactone (C6HSL) $(35,54)$. These AHL signal molecules freely diffuse out of the cells and increase in proportion to the number of bacterial cells until sufficient AHLs accumulate to bind LuxR, an AHL receptor and

Corresponding author: D. A. Kluepfel; E-mail address: Daniel.Kluepfel@ars.usda.gov

* The $e$-Xtra logo stands for "electronic extra" and indicates that Figure 5 appears in color online.

http://dx.doi.org/10.1094/PHYTO-04-11-0111

This article is in the public domain and not copyrightable. It may be freely reprinted with customary crediting of the source. The American Phytopathological Society, 2012. transcription factor. LuxR dimerizes to modulate the expression of select genes, leading to changes in the behavior of the bacterial symbiont and subsequent production of bioluminescence in the mollusk host $(16,17,57)$. Several LuxI and LuxR homologs have been identified and characterized from a wide range of freeliving, symbiotic, and pathogenic gram-negative bacterial species $(66,69)$. These proteins regulate a diverse range of phenotypes, including antibiotic production, toxin generation, synthesis of enzymes involved in secondary metabolism, virulence, motility, and biofilm formation $(8,21,46)$.

Brenneria rubrifaciens is the causal agent of deep bark canker (DBC) of walnut, first described in California (71). DBC typically afflicts mature ( $\geq 15$ years old) English walnut trees and is one of three commercially important bacterial diseases of walnut along with crown gall (caused by Agrobacterium tumefaciens) and walnut blight (caused by Xanthomonas arboricola pv. juglandis). It is characterized by vertical cracks in the central trunk and large scaffold branches that exude a discolored sap and serve as an infection site for other microorganisms. Disease symptoms are not observed on young trees but the pathogen can be found in sap of symptomless trees of various ages, including cultivars and species used for budwood and rootstock production, suggesting a widespread distribution of natural populations of $B$. rubrifaciens $(62,63)$. Intensity of symptoms on walnut is cultivar specific (32), with the once dominant 'Hartley' being replaced in orchards due to its susceptibility to DBC. Hartley once accounted for the majority of walnut trees planted in California and is now the second most planted cultivar, occupying $17 \%$ of the total acreage, while 'Chandler' occupies $33 \%$ of the total acreage (33). Seventeen other commercially important cultivars vary from moderately susceptible to highly susceptible to DBC (32). Adaptation of improved midwinter irrigation regimens and modified tree shaker methods by the walnut industry has helped reduce disease inci- 
dence in many orchards but recent reports of DBC have been described on Chandler, the dominant cultivar in newer orchards. The late-onset nature of DBC and presence of the pathogen in symptomless trees indicate the importance of some stimuli or possible QS regulation which mediates pathogenesis.

When cultured in vitro, $B$. rubrifaciens produces copious amounts of the water-soluble red pigment rubrifacine, which has an unknown role in pathogenesis (25). B. rubrifaciens transposon mutants defective in rubrifacine production were characterized previously (42). One of these pigment-deficient mutants, Br-212, was disrupted in the lux I homolog, bruI, and was unable to produce rubrifacine or elicit a hypersensitive reaction (HR) in tobacco. Br-212 was also attenuated in virulence on tissuecultured walnut plants, implicating the involvement of QS in the regulation of these phenotypes. Preliminary work revealed two other Brenneria spp., B. nigrifluens and B. salicis, that also induce pigment production in $\mathrm{Br}-212$ on solid media, suggesting that these species produced similar signaling compounds (42). B. nigrifluens causes the disease shallow bark canker in walnut (70). Symptoms are characterized by small cracks in the trunk of the tree that lightly ooze sap. B. salicis is the causal agent of watermark disease in willow trees, characterized by wilted leaves and discolored bark (39). Recently, the major AHL of B. salicis was identified as 3OC6HSL (31). Here, we report the major AHLs of B. rubrifaciens as 30C6HSL and C6HSL, which were identified by high-performance liquid chromatography (HPLC) and mass spectrometry (MS) analysis. In addition, a genetic locus with open reading frames (ORFs) designated bruI and bruR homologous to $l u x \mathrm{I}$ and $l u x \mathrm{R}$ are described. Addition of various synthetic AHLs and cell-free extracts from B. salicis and B. nigrifluens resulted in restored pigment production in the $B$. rubrifaciens mutant $\mathrm{Br}-212$, and the ability to elicit an HR in tobacco are also described.

\section{MATERIALS AND METHODS}

Bacterial strains and media used. Bacterial strains used are listed in Table 1. The media types used were YDC (yeast extract at $10 \mathrm{~g} / \mathrm{liter}$, dextrose at $20 \mathrm{~g} / \mathrm{liter}$, and calcium carbonate at $20 \mathrm{~g} /$ liter), YDCA (YDC plus agar at $15 \mathrm{~g} / \mathrm{liter}$ ), and TSB (BBL trypticase soy broth at $30 \mathrm{~g} /$ liter [Becton Dickinson, MD]).

Rubrifacine induction by crude extracts. Ethyl acetate (EtOAc) extracts were prepared by growing Brenneria spp. and mutant $\mathrm{Br}-212$ in $250 \mathrm{ml}$ of TSB at $28^{\circ} \mathrm{C}$ for 2 days, after which the cells were pelleted by centrifugation. The culture fluid was filtered through a $0.2-\mu \mathrm{M}$ filter and extracted twice with an equal volume of acidified ethyl acetate $(0.1 \mathrm{ml} \mathrm{HOAc/liter}$ of EtOAc). The extract was reduced to a volume of $1 \mathrm{ml}$ by rotary evaporation and stored at $-20^{\circ} \mathrm{C}$. Each extract $(30 \mu \mathrm{l})$ was spread on YDCA plates (in duplicate) and subsequently plated with Br-212. Rubrifacine production was assessed visually after incubation at $28^{\circ} \mathrm{C}$ for $48 \mathrm{~h}$. Alternatively, a $50-\mu \mathrm{l}$ aliquot from each extract was added to $10 \mathrm{ml}$ of YDC and inoculated with $\mathrm{Br}-212$ (optical density at $600 \mathrm{~nm}\left[\mathrm{OD}_{600}\right]=0.05$ or $\approx 10^{8} \mathrm{CFU} / \mathrm{ml}$ ). All samples were examined for pigment production by visual examination. Selected samples were analyzed for absorbance by scanning at a

TABLE 1. Bacterial strains used in this study ${ }^{\mathrm{a}}$

\begin{tabular}{ll}
\hline Strains & \multicolumn{1}{c}{ Source } \\
\hline Chromobacterium violaceum CV026 & McClean et al. (43) \\
Escherichia coli EC1 & Antunes et al. (4) \\
Brenneria nigrifluens ATCC 13028 & ATCC \\
B. salicis 15712 & ATCC \\
B. rubrifaciens $6 \mathrm{D} 370$ & Azad and Kado (6) \\
Br-212 bruI mutant & McClean and Kluepfel (42) \\
Br-415 rpoN-like mutant & This study \\
\hline
\end{tabular}

a ATCC $=$ American Type Culture Collection. wavelength of 300 to $700 \mathrm{~nm}$ using a DU 800 spectrophotometer (Beckman, CA). Experiments were done in duplicate.

Rubrifacine induction with synthetic AHLs. N-butryl-DLhomoserine lactone (C4HSL), C6HSL, 3OC6HSL, N-heptanoylDL-homoserine lactone (C7HSL), N-octanoyl-DL-homoserine lactone (C8HSL), N-(3-oxooctanoyl)-DL-homoserine lactone (3OC8HSL), N-decanoyl-DL-homoserine lactone (C10HSL), and $\mathrm{N}$-dodecanoyl-DL-homoserine lactone (C12HSL) were purchased from Sigma-Aldrich (St. Louis) and dissolved in acidified EtOAc to a working concentration of $10 \mathrm{mM}$. Synthetic AHL preparation $(5 \mu \mathrm{l})$ plus $10 \mu \mathrm{l}$ of sterile water was spread on YDCA plates and allowed to air dry. Subsequently, Br-212 was streaked from frozen stocks directly on the plates. Samples were examined for rubrifacine production after incubation at $28^{\circ} \mathrm{C}$ for $48 \mathrm{~h}$. Experiments were done in triplicate.

Each of the synthetic AHL preparations $(10 \mu \mathrm{l})$ was added to YDC liquid medium at a concentration of $10 \mu \mathrm{M}$. The AHLamended YDC was inoculated with $\mathrm{Br}-212\left(\mathrm{OD}_{600}=0.05\right)$. Nonamended YDC medium, YDC inoculated with $\mathrm{Br}-212$ alone, and wild-type $B$. rubrifaciens 6D370 (WT) were used as controls. All cultures, in triplicate, were incubated at $28^{\circ} \mathrm{C}$ on a gyratory shaker $(211 \mathrm{rpm})$ and examined after $72 \mathrm{~h}$ for rubrifacine production. All samples were examined visually for pigment production. For spectrophotometric analysis, $1 \mathrm{ml}$ of each culture was transferred to a $1.5-\mathrm{ml}$ microcentrifuge tube and centrifuged at maximum speed $(20,000 \times g)$ for $2 \mathrm{~min}$. The samples were analyzed as described above but at a wavelength of 400 to $700 \mathrm{~nm}$. Experiments were done in duplicate.

HPLC analysis. B. rubrifaciens $6 \mathrm{D} 370$ and mutant $\mathrm{Br}-212$ were grown in $10-\mathrm{ml}$ YDC cultures at $28^{\circ} \mathrm{C}$ to $\mathrm{OD}_{600}=2$. The cultures were extracted twice in acidified EtOAc and the extracts dried to completion under nitrogen gas. Both samples were reconstituted in $200 \mu \mathrm{l}$ of $50 \%$ methanol and separated using C18 reverse-phase HPLC (10 to $100 \%$ methanol gradient, flow rate $1 \mathrm{ml} / \mathrm{min}$, duration $70 \mathrm{~min}$ ). Fractions were assayed for acyl-HSL activity using the Escherichia coli reporter strain EC21 (4). B. rubrifaciens 6D370 extract was spiked with 3OC6HSL and C6HSL and separated using C18 reverse-phase HPLC as described above to quantify total endogenous AHLs. Standard curves for both AHLs were generated using synthetic 3OC6HSL ( 1 to $4 \mathrm{nM}$ ) and C6HSL ( 8 to $20 \mathrm{nM}$ ) and reporter strain E. coli EC21.

Thin-layer chromatography analysis. EtOAc extracts $(0.4$ to $1.0 \mu \mathrm{l})$ containing AHLs from Brenneria strains were spotted on 10-by-10-cm partisil KC18 reverse-phase thin-layer chromatography (TLC) glass plates (Whatman, $\mathrm{NJ}$ ) and developed with 60:40 methanol $/ \mathrm{H}_{2} \mathrm{O}$ in a glass TLC chamber. AHL standards C6HSL and 30C6HSL were prepared in acidified EtOAc at 0.5 and $1 \mathrm{mM}$ concentrations. B. salicis crude extract was diluted (1:4) in acidified EtOAc before spotting. Extracts from B. rubrifaciens and $B$. nigrifluens were applied undiluted. Plates were overlaid with $52 \mathrm{ml}$ of $0.8 \%$ Luria-Bertani agar and kanamycin at $25 \mathrm{mg} /$ liter seeded with $2 \mathrm{ml}$ of an overnight culture of the AHL indicator strain Chromobacterium violaceum CV026 and incubated at $28^{\circ} \mathrm{C}$ for 12 to $16 \mathrm{~h}$ (43).

Liquid chromatography-mass spectrometry analysis. $B$. rubrifaciens and B. nigrifluens EtOAc extracts were diluted 1:5 prior to liquid chromatography-mass spectrometry (LCMS) analysis. All spectra were acquired on an LTQ Orbitrap XL mass spectrometer equipped with a Surveyor HPLC system and an electrospray ionization source (ThermoFisher, San Jose, CA), operating in the positive ion mode. The mobile phase was composed of $0.1 \%$ formic acid in water (solvent $\mathrm{A}$ ) and $0.1 \%$ formic acid in acetonitrile (solvent B). Analytical samples were separated on a Symmetry C18 column $(3.5 \mu \mathrm{m}, 2.1$ by $150 \mathrm{~mm})$ (Waters, Milford, MA) using a linear gradient of 5 to $90 \%$, solvent B/solvent $\mathrm{A}$, over $60 \mathrm{~min}$ at a flow rate of $200 \mathrm{ml} / \mathrm{min}$. Mass spectra were acquired using Xcalibur, version 2.0.5 (ThermoFinnigan). The spectra were externally calibrated using malto- 
oligosaccharides and then further calibrated internally to $<2 \mathrm{ppm}$ with the lock mass tool (19).

Tobacco leaf infiltrations. TSB cultures $(10 \mathrm{ml}$ each) of $B$. rubrifaciens $6 \mathrm{D} 370$ (wild type) and mutant strains $\mathrm{Br}-212$ and $\mathrm{Br}$ 415 (a B. rubrifaciens 6D370 transposon mutant impaired in HR induction but not in rubrifacine production) were grown for 3 days at $28^{\circ} \mathrm{C}$, subcultured $1: 10$ in fresh TSB, and incubated overnight at $28^{\circ} \mathrm{C}$ on a rotary shaker at $211 \mathrm{rpm}$. The cultures were centrifuged at $12,000 \times g$ for $3 \mathrm{~min}$ at room temperature. The supernatants were decanted and the pellets suspended in $2 \mathrm{ml}$ of sterile milli-Q water and adjusted to $\mathrm{OD}_{600}=1.0\left(\approx 10^{9} \mathrm{CFU} / \mathrm{ml}\right)$. AHL extracts were added to $2 \mathrm{ml}$ of bacterial suspension to generate $\mathrm{AHL}^{+}$samples $\left(10 \mu \mathrm{M}\right.$ AHL). The $\mathrm{AHL}^{-}$controls were not amended with any AHLs. Each suspension was pressure infiltrated into at least two leaves on different Nicotiana benthamiana tobacco plants using $1 \mathrm{ml}$ Kendall tuberculin syringes (Tyco, MA). The infiltrated areas were circled with a black marker and checked for HR development at 36 to $48 \mathrm{~h}$ postinoculation. The plants were kept under laboratory lighting and temperature for the duration of the experiment. Experiments were done in triplicate.

Cloning and genetic analysis. The ORF bruR was identified by sequencing $3^{\prime}$ of the Tn5 (Epicentre) insertion in the bruI gene. The $b r u R$ gene was amplified by polymerase chain reaction (PCR) from B. rubrifaciens 6D370 in the following cocktail: $0.4 \mu \mathrm{M}$ 5' primer BruR-F (5'-CGGGATCCATGTCTTTTTTT TGGTCT-3') and $0.4 \mu \mathrm{M} 3^{\prime}$ primer BruR-R (5'-ATCAGCTG TCAAAAAGGAAGAGGCTTG-3'), 1× GoTaq colorless mastermix, $\approx 100 \mathrm{ng}$ of $B$. rubrifaciens $6 \mathrm{D} 370$ genomic DNA, and nuclease-free water up to $25 \mu \mathrm{l}$. The following cycle conditions were used: $94^{\circ} \mathrm{C}$ for $5 \mathrm{~min} ; 30$ cycles of $94^{\circ} \mathrm{C}$ for $15 \mathrm{~s}, 60^{\circ} \mathrm{C}$ for $30 \mathrm{~s}$, and $72^{\circ} \mathrm{C}$ for $45 \mathrm{~s} ; 1$ cycle of $72^{\circ} \mathrm{C}$ for $2 \mathrm{~min}$; and a hold at $4^{\circ} \mathrm{C}$. The PCR product was cloned into pGEM-T (Promega Corp., Madison, WI) according to the manufacturer's instructions and submitted for sequence analysis at the University of California DNA Sequencing Facility (University of California, Davis). The resulting nucleotide sequence was edited using Sequencher 4.7 (Gene Code Corp., MI). Blast analysis was performed using the BlastN and BlastX servers (3).

\section{RESULTS}

Brenneria extracts were analyzed for rubrifacine induction in $B$. rubrifaciens mutant $\mathrm{Br}-212$. Extracts from $B$. rubrifaciens, $B$. salicis, and $B$. nigrifluens restored pigment production to the bruI mutant strain Br-212 in assays using both solid and liquid
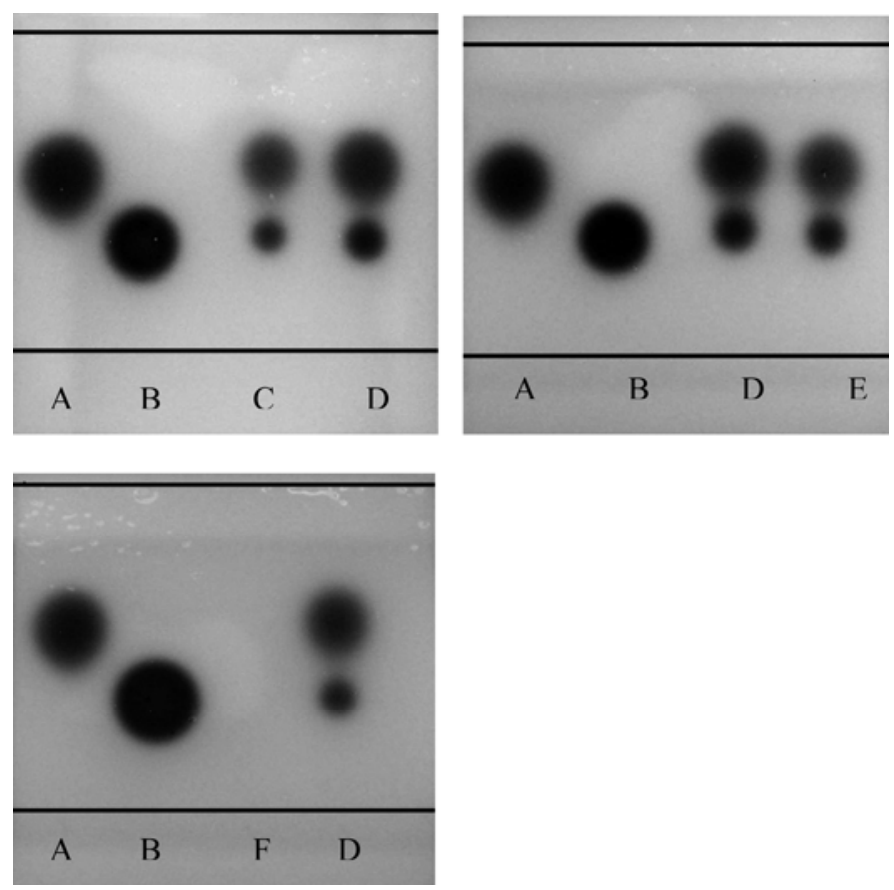

Fig. 2. Thin-layer chromatography (TLC) analysis of Brenneria spp. culture filtrate extracts. Crude ethyl acetate extracts were resolved on $\mathrm{C}_{18}$ reversephase TLC glass plates. Acyl homoserine lactones (AHLs) were visualized by gel overlay of the TLC plates with reporter strain Chromobacterium violaceum CV026. Spots indicate pigment production in the presence of AHLs by CV026. A, $N$-(3-oxohexanoyl)-homoserine lactone (3OC6HSL); B, N-hexanoylhomoserine lactone (C6HSL); C, Brenneria nigrifluens ATCC 13028; D, B. rubrifaciens 6D370; E, B. salicis ATCC 15712; and F, Br-212.

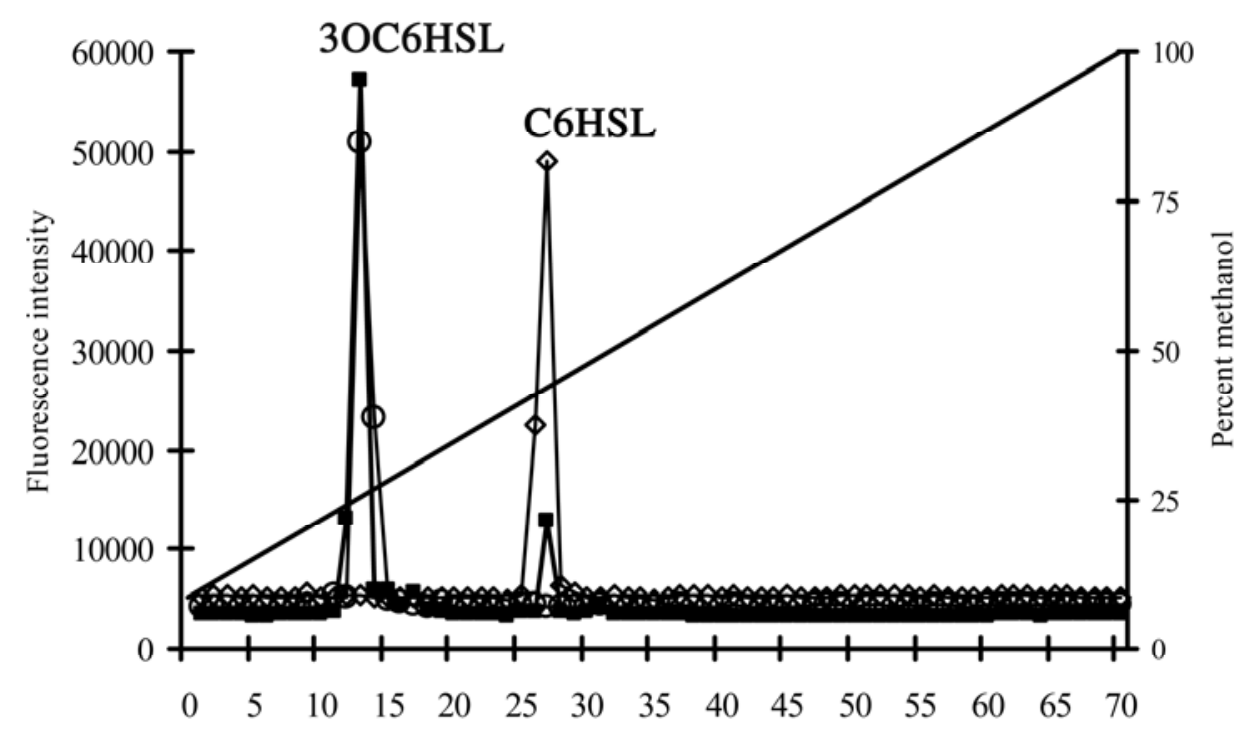

Fraction number

Fig. 1. Methanol-gradient high-performance liquid chromatography (HPLC) separation of acyl homoserine lactones (AHLs) from Brenneria rubrifaciens 6D370 and co-elution with standards $N$-(3-oxohexanoyl)-homoserine lactone (3OC6HSL) and N-hexanoyl-homoserine lactone (C6HSL). HPLC analysis of ethyl acetateextracted culture fluid from B. rubrifaciens 6D370. AHLs containing fractions were identified using an Escherichia coli reporter strain EC21. Peak sizes correlate with overall abundance of AHL product. AHL-induced green fluorescent protein fluorescence is reported in fluorescence intensity units. The solid line indicates the percent methanol. Closed squares $(\boldsymbol{\square})$ indicate the B. rubrifaciens 6D370 extract, open diamonds $(\diamond)$ indicate the C6HSL standard, and open circles $(\bigcirc)$ represent the 3OC6HSL standard. 
medium. Extracts from bruI mutant Br-212 did not induce pigment production on YDCA and in YDC liquid medium (data not shown).

HPLC analysis of wild-type B. rubrifaciens 6D370 culture supernatant revealed two abundant AHL species, 3OC6HSL and C6HSL (Fig. 1). Detection of the AHLs was confirmed using the AHL reporter strain E. coli EC21. HPLC analysis of mutant Br212 extracts did not reveal any detectable peaks (data not shown). Using EC21 and synthetic AHLs, we generated a standard curve and determined that the concentrations of 30C6HSL and C6HSL in a $10-\mathrm{ml}$ culture volume were 612 and $14.8 \mathrm{nM}$, respectively. TLC analysis of crude EtOAc extracts from the culture fluid of $B$. rubrifaciens, B. nigrifluens, and B. salicis, using a $C$. violaceum CV026 reporter strain, showed the same AHL patterns corresponding to 30C6HSL and C6HSL (Fig. 2). Extract prepared from bruI mutant $\mathrm{Br}-212$ did not show any spots on the TLC plate (Fig. 2). The AHLs 3OC6HSL and C6HSL were identified in extracts of both $B$. rubrifaciens $6 \mathrm{D} 370$ and B. nigrifluens American Type Culture Collection (ATCC) 13028 by LCMS. Spectra from extracted ion chromatograms from both extracts revealed masses (m/z 214 and 200) identical to 3OC6HSL and C6HSL, respectively (Figs. 3 and 4).

We next explored whether the synthetic AHLs 3OC6HSL, C6HSL, C7HSL, C8HSL, and 3OC8HSL were sufficient to induce rubrifacine production in $\mathrm{Br}-212$ using both plate-based
(YDCA) and liquid (YDC) growth assays (Figs. 5 and 6). 3OC6HSL strongly induced rubrifacine production and this response was stronger than C6HSL at the same concentration of $10 \mu \mathrm{M}$ in YDC (Fig. 6). C7HSL, C8HSL, and 3OC8HSL also restored pigment production in $\mathrm{Br}-212$ (Table 2). Previously, we showed that bruI was required for the ability of B. rubrifaciens to induce HR formation in tobacco leaves (42). Br-212 amended with 3OC6HSL or C6HSL could now induce HR on tobacco. Intriguingly, C7HSL and C8HSL also induced an HR in tobacco colonized with Br-212 similar to the wild-type strain. Br-212 alone did not induce an HR (Table 2). Br-415, an $\mathrm{HR}^{-}$mutant, with an insertion in a genetic region with homology to genes encoding RpoN type $\sigma$ factors, remained $\mathrm{HR}^{-}$even after addition of 30C6HSL, C6HSL, or C8HSL, indicating that the restorative phenotype was restricted to bruI mutant Br-212. C4HSL, C10HSL, and C12HSL, when amended at $10 \mu \mathrm{M}$, did not induce rubrifacine production in Br-212 cultured in YDC (Table 2).

Sequence analysis of the 651-bp bruI locus in mutant $\mathrm{Br}-212$ identified another ORF in the reverse orientation (Fig. 7), revealing a luxI-luxR like genetic locus. This additional 735-bp ORF, labeled bruR, exhibited nucleotide homology (74\% identical, E value $\left.=5 \times 10^{-55}\right)$ to $\exp \mathrm{R}(729 \mathrm{bp})$ from Pectobacterium carotovorum subsp. carotovorum strain $\mathrm{BC} 1$ using BlastN. The predicted BruR (244 amino acids) shared the highest amino acid identity (59\%) with YpeR from Yesinia pestis (NP_669049.1)

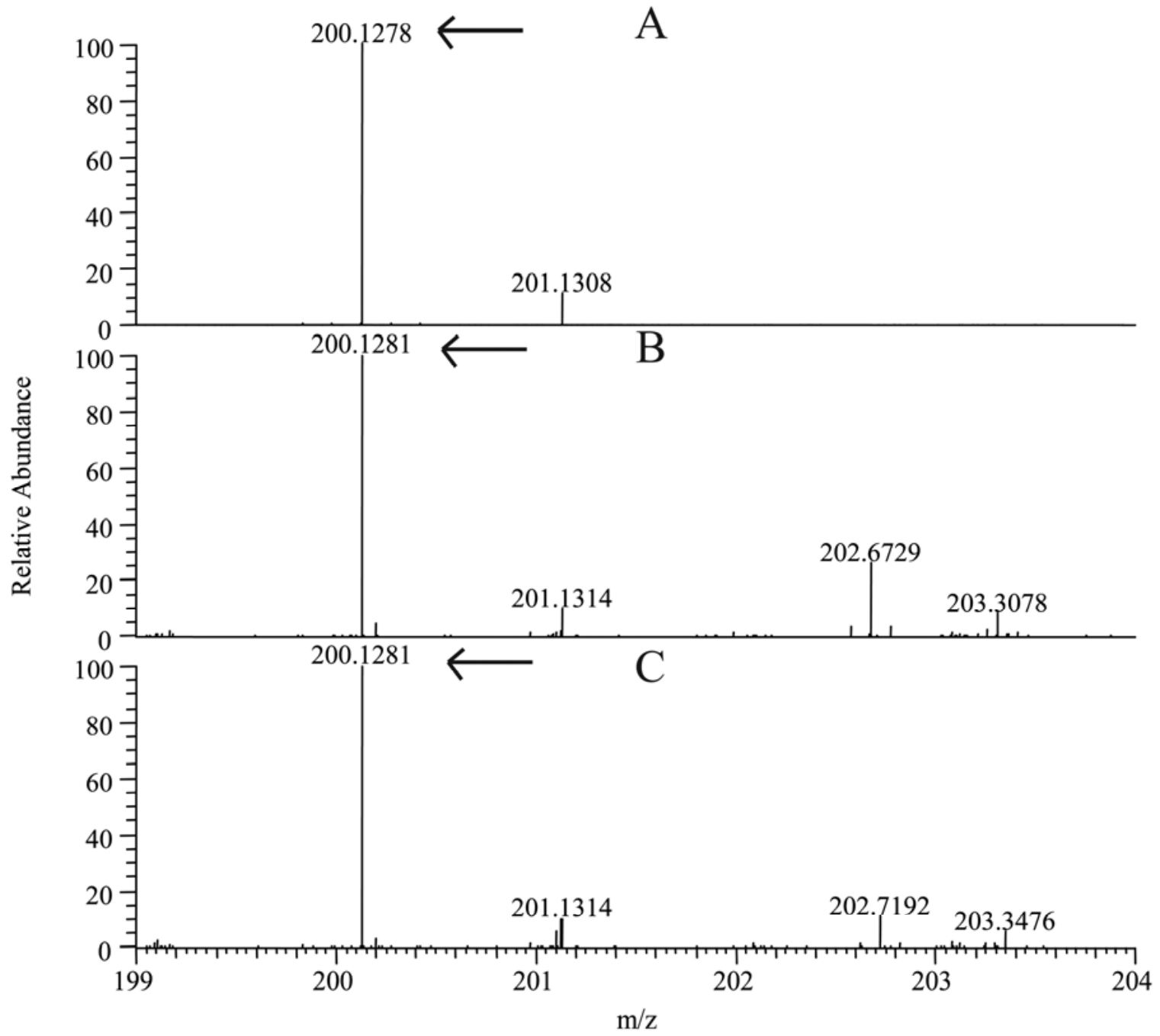

Fig. 3. Liquid chromatography-mass spectrometry (LCMS) analysis of Brenneria rubrifaciens and B. nigrifluens culture filtrate extracts for the presence of Nhexanoyl-homoserine lactone (C6HSL). C6HSL was identified in extracted ion chromatograms from Brenneria sp. extracts and analyzed by high resolution MS. Peaks for C6HSL at m/z 200 (indicated by the arrows) and $\mathrm{m} / \mathrm{z} 201$ (13C mass) are observed in A, the synthetic standard; B, B. nigrifluens; and C, B. rubrifaciens, respectively. 
using BlastX. Another LuxR-like protein, EchR (Q46967.1) from Dickeya chysanthemi, exhibited the highest match to BruR in the Swissprot database ( $72 \%$ identity, $E$ value $\left.=5 \times 10^{-98}\right)$.

\section{DISCUSSION}

Bacteria in soil or associated with plants occur in complex microbial communities $(20,58)$. Chemical signaling between the different bacterial species in environments such as plant sap or the rhizosphere can influence the composition and behavior of the resident bacterial community $(5,7,27)$. AHLs are one class of chemical signals utilized by bacteria for both intra- and interspecies communication $(45,49)$. Production and detection of particular AHLs by bacterial species is highly variable, with some species producing multiple AHLs or responding to exogenous AHL signals produced by other bacteria $(14,60)$. This may be particularly advantageous when a bacterial species resides in a competitive environment containing both related and unrelated species.

Different bacterial species from the same environment or host often produce similar or identical AHLs, providing the opportunity for cross species communication. Human pathogenic strains of Pseudomonas aeruginosa PAO1 and Serratia liquefaciens synthesize the same major AHL molecule, C4HSL $(23,72)$, and the maize pathogens D. zeae and Pantoea stewartii both produce 3OC6HSL (44). Soilborne species such as the legume- nodulating Rhizobium leguminosaurm bv. viciae 8401 and the animal pathogen Burkholderia pseudomalleli produce a wide variety of AHLs and one, C8HSL, is produced by both $(56,73)$. Other soil microbes producing C8HSL include Sinorhizobium meliloti, Mesorhizobium meliloti, and Burkholderia glumae (61), facilitating cross-talk across different bacterial genera. One clear example of AHL-mediated cross-talk among different bacterial

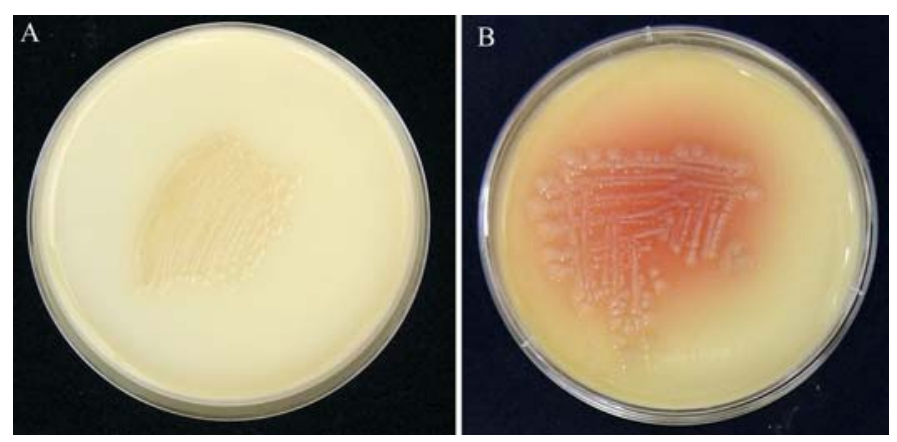

Fig. 5. Rubrifacine induction in $\mathrm{Br}-212$ on yeast extract-dextrose-calcium carbonate agar (YDCA) medium. Brenneria rubrifaciens bruI mutant $\mathrm{Br}-212$ was streaked from frozen stock on A, YDCA plates alone or $\mathbf{B}$, YDCA plates prespread with $10 \mu \mathrm{l}$ of $10 \mathrm{mM} \mathrm{N}$-(3-oxohexanoyl)-homoserine lactone (3OC6HSL) in acidified ethyl acetate across the surface. Samples were examined for pigment production after 3 days at $28^{\circ} \mathrm{C}$.

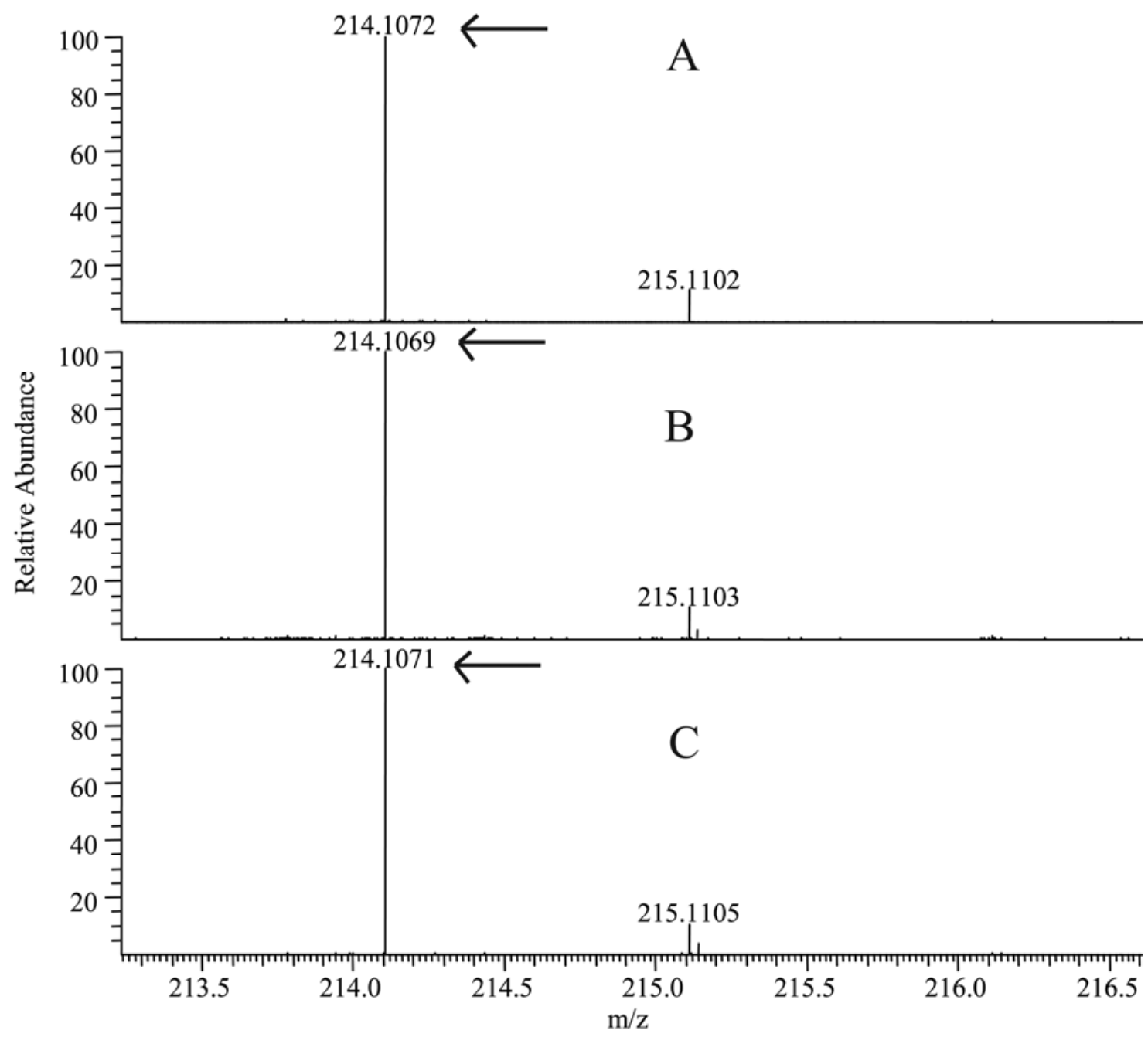

Fig. 4. Liquid chromatography-mass spectrometry (LCMS) analysis of Brenneria rubrifaciens and B. nigrifluens culture filtrate extracts for the presence of $N$-(3-oxohexanoyl)-homoserine lactone (3OC6HSL). 30C6HSL was identified in extracted ion chromatograms from Brenneria sp. extracts and analyzed by high resolution MS. Peaks for 3OC6HSL at m/z 214 (indicated by the arrows) and $\mathrm{m} / \mathrm{z} 215$ (13C mass) are observed in A, the synthetic standard; B, B. nigrifluens; and C, B. rubrifaciens, respectively. 
species has been described between Burkholderia cepacia and Pseudomonas aeruginosa, phylogenetically distinct species that colonize the same environment (i.e., the airways of cystic fibrosis patients) $(13,51)$. P. aeruginosa can activate the expression of virulent factors in B. cepacia in mixed biofilms in vivo and in vitro, indicating that cell-to-cell communication between different genera occurs in mixed communities.

Closely related bacteria sometimes use similar AHL signals even if they occupy different environments. Plant pathogens Erwinia amylovora and Pectobacterium carotovorum have different hosts but still synthesize 30C6HSL and C6HSL as AHL products (8). Similarly, the two Brenneria spp., Brenneria salicis and $B$. rubrifaciens, where QS has been described, exhibit different host ranges yet produce structurally identical AHLs. $B$. salicis, the causal agent of watermark disease of willow (Salix spp.), also occurs as an endophyte in alder and poplar trees $(38,39)$. Yet only willow trees support high $B$. salicis populations and develop disease symptoms. The mechanism underlying disease development is not understood but QS has been implicated in the induction of cellulase activity in B. salicis isolates (31). In a similar manner, $B$. rubrifaciens and $B$. nigrifluens are also found in symptomless walnut trees (32).

QS is one regulatory pathway that may play a role in disease occurrence in these species. B. salicis extract induces pigment production in $B$. rubrifaciens mutant $\mathrm{Br}-212$ because it contains molecules with chemical structures (3OC6HSL and C6HSL) identical to those produced by B. rubrifaciens 6 D370 (Fig. 2). However, these signals may modulate very different effects in each species. Brenneria alni and Brenneria quercina were not able to induce rubrifacine production in $\mathrm{Br}-212$ on YDCA plates but, interestingly, crude extract from $B$. nigrifluens did. TLC analysis using reporter strain $C$. violaceum CV026 demonstrates that $B$. nigrifluens ATCC 13028 extract contains compounds with the same mobility as AHLs from B. rubrifaciens 6D370 and $B$. salicis ATCC 15712 (Fig. 4).

Three complimentary methods-HPLC, TLC, and LCMSconfirm the signal molecules produced by $B$. rubrifaciens to be 30C6HSL and C6HSL (Figs. 1 to 4), with the former being the most abundant species produced in 40 -fold excess of the latter. TLC and MS results confirmed that $B$. nigrifluens also produces similar AHLs (3OC6HSL, and C6HSL) (Figs. 3 and 4) and therefore, unsurprisingly, extracts from this species induce pigment production in mutant $\mathrm{Br}-212$. Both $B$. rubrifaciens and B. nigrifluens share the same restricted host range (walnut) and both cause distinctive bark canker diseases $(6,70,71)$. However, severe cases of shallow bark canker have symptoms very similar to DBC $(37,52)$ and both $B$. nigrifluens and $B$. rubrifaciens have been isolated from trees with DBC (71). Because both diseases sometimes occur in adjacent tissue, cross-talk may occur between $B$. rubrifaciens and $B$. nigrifluens during colonization of the walnut host.

Heterologous expression of bruI in Escherichia coli complements the pigment deficient phenotype of mutant $\mathrm{Br}-212$ in plate bioassays (42), indicating that bruI expression mediates production of signaling molecules required for rubrifacine production. C7HSL, C8HSL, and 3OC8HSL were not detected in extracts from $B$. rubrifaciens $6 \mathrm{D} 370$ but still induced rubrifacine production in $\mathrm{Br}-212$ (Table 2), demonstrating that the mutant $\mathrm{B}$. rubrifaciens $\mathrm{Br}-212$ responds to AHLs which it is unable to synthesize. The bruR ORF is the only lux $\mathrm{R}$ homolog identified from this

TABLE 2. Induction of wild-type phenotypes in $\mathrm{Br}-212$ by various synthetic acyl homoserine lactones (AHLs) ${ }^{\mathrm{a}}$

\begin{tabular}{lcc}
\hline AHL added $^{\mathrm{b}}$ & Rubrifacine production $^{\mathrm{c}}$ & HR in $^{\mathrm{cobacco}}{ }^{\mathrm{d}}$ \\
\hline C4HSL & - & - \\
C6HSL & + & + \\
3OC6HSL & + & + \\
C7HSL & + & + \\
C8HSL & + & + \\
3OC8HSL & + & + \\
C10HSL & - & - \\
C12HSL & - & - \\
None & - & -
\end{tabular}

a AHLs were purchased from Sigma-Aldrich, suspended in acidified ethyl acetate, and added to Brenneria rubrifaciens mutant $\mathrm{Br}-212 \mathrm{in} 10 \mathrm{ml}$ of yeast extract-dextrose-calcium carbonate at $10 \mu \mathrm{M}$. Samples were evaluated visually for pigment production after 3 days at $28^{\circ} \mathrm{C}$ and rotary shaking at $215 \mathrm{rpm}$.

${ }^{\mathrm{b}} \mathrm{C} 4 \mathrm{HSL}=\mathrm{N}$-butryl-DL-homoserine lactone, C6HSL $=$ N-hexanoyl-homoserine lactone, $3 \mathrm{OC} 6 \mathrm{HSL}=\mathrm{N}$-(3-oxohexanoyl)-homoserine lactone, $\mathrm{C7HSL}=$ N-heptanoyl-DL-homoserine lactone, C8HSL $=\mathrm{N}$-octanoyl-DL-homoserine lactone, $3 \mathrm{OC} 8 \mathrm{HSL}=\mathrm{N}$-(3-oxooctanoyl)-DL-homoserine lactone, $\mathrm{C} 10 \mathrm{HSL}=$ $\mathrm{N}$-decanoyl-DL-homoserine lactone, and C12HSL = N-dodecanoyl-DLhomoserine.

$\mathrm{c}+$ and - denote presence or absence of rubrifacine, respectively. Nicotiana benthamiana (tobacco) leaves were pressure-infiltrated with optical density at $600 \mathrm{~nm}$ suspensions $=1.0$ of B. rubrifaciens mutant $\mathrm{Br}-212$ and evaluated 36 to $40 \mathrm{~h}$ postinoculation for the occurrence of a hypersensitive reaction (HR).

d + and - denote HR or no reaction, respectively.

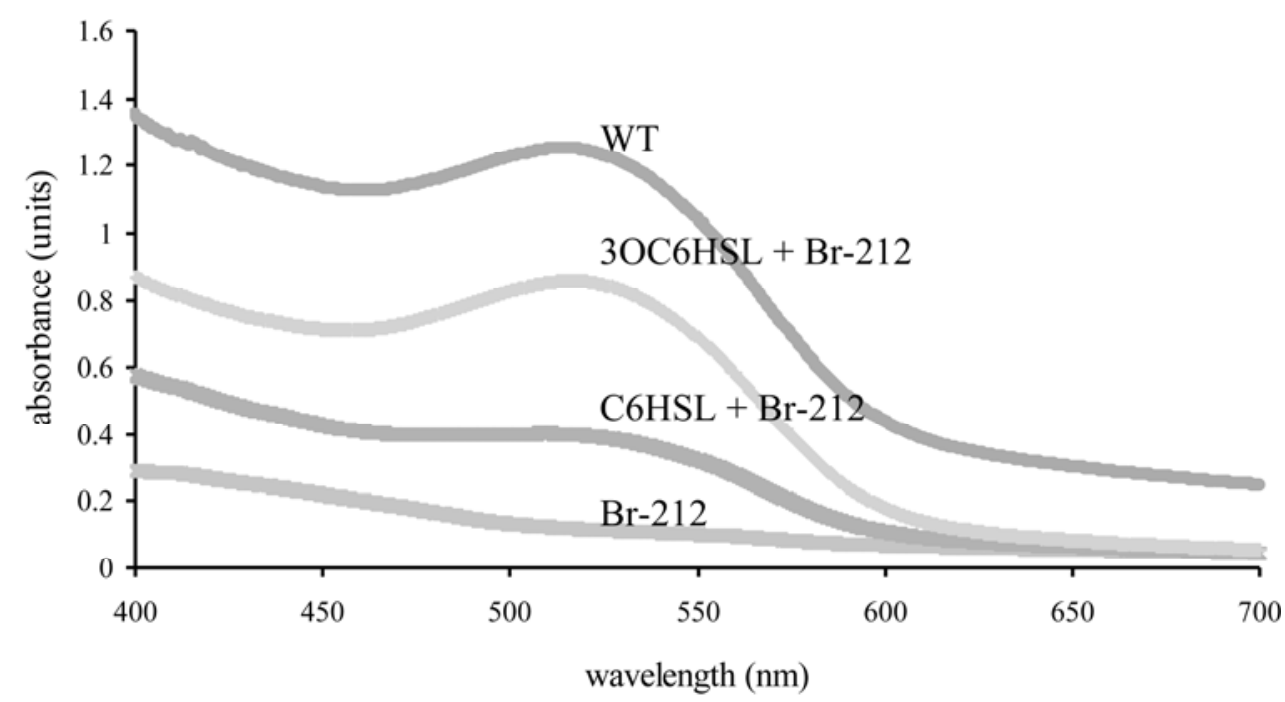

Fig. 6. Rubrifacine production in Brenneria rubrifaciens mutant $\mathrm{Br}-212$ by synthetic $N$-(3-oxohexanoyl)-homoserine lactone (3OC6HSL) and N-hexanoyl-homoserine lactone (C6HSL). Absorbance scans from cell-free supernatants of wild-type B. rubrifaciens 6D370 (WT), mutant Br-212, and mutant Br-212 amended with $10 \mu \mathrm{M}$ 30C6HSL and $10 \mu \mathrm{M}$ C6HSL. Samples were evaluated using spectrophometric analysis after 3 days of incubation at $28^{\circ} \mathrm{C}$ and rotary shaking at $215 \mathrm{rpm}$. Each sample was prepared in triplicate. 
species and is the best candidate for mediating the response to the small-chain AHLs. Several LuxR homologs have been shown to respond to multiple AHLs, including TraR and CviR from $A$. tumefaciens and $C$. violaceum, respectively $(43,55)$. Alternatively, bacteria can also respond to foreign AHLs by employing orphan LuxR homologs similar to those found in Pseudomonas aeruginosa (18), E. coli (14), and Burkholderia cenocepacia (40).

Regulation of rubrifacine production by AHL-mediated QS suggests a role for the pigment at high population densities. $B$. rubrifaciens populations reach $10^{10} \mathrm{CFU} / \mathrm{ml}$ in diseased trees (53). No function in virulence has yet been attributed to rubrifacine (42). The indigoidine pigment of D. chrysanthemi and ferrosamine A of Pectobacterium rhapontici function as a scavenger of oxygen radicals and siderophore, respectively, which has been suggested to confer a selective advantage to these phytopathogens. $(26,50)$. Therefore, rubrifacine may also confer a similar selective advantage for Brenneria rubrifaciens in walnut.

Many plant-pathogenic bacteria trigger an $\mathrm{HR}$ in non-host plants species (34). This HR phenomenon, a type of programmed plant cell death, is regulated in many species by the type III secretion system (T3SS) encoded by hypersensitive response and pathogenicity ( $h r p$ ) genes (1). The T3SS translocates bacterial effector proteins directly into eukaryotic host cells, allowing for modulation of the host signaling and defense (15). QS-mediated control of TSS3-mediated HR has been described for other species, including Erwinia amylovora, Dickeya dadantii, Pantoea stewartii subsp. stewartii, and Pectobacterium atrosepticum) (36, 47,67). Application of exogenous AHLs enabled B. rubrifaciens mutant $\mathrm{Br}-212$ to elicit an HR in tobacco leaves similar to wildtype B. rubrifaciens. E. amylovora and D. chrysanthemi hrp mutants are defective in HR and attenuated in virulence, similar to Br-212 (9,12). The HR results indicate that B. rubrifaciens also has genes involved in virulence and HR elicitation regulated by AHL-mediated QS.

Host cultivar-specific chemical profiles may contribute to walnut disease susceptibility. Many eukaryotes can influence AHL-mediated QS regulation in bacteria by utilizing either smallmolecule AHL mimics or degradative enzymes. QS inhibitory compounds have been described from Penicillium spp. and algae, most notably Delsia pulchra. $(41,48,59)$. Characterization of the chemical nature of QS compounds that influence bacterial QS in many terrestrial plants is still in the preliminary stages but QSmodulating activity has been described from some plants, including Acacia nilotica L., garlic bulb, Medicago truncatula, Quercus virginiana, and Combretum albiflorum (2,30,64). Given these findings, it is possible that specific walnut cultivars (32) contain compounds that modulate bacterial QS, contributing to the striking differences in disease susceptibility observed between walnut cultivars. Elucidation of this interaction will facilitate future breeding of disease-resistant cultivars.

\section{$651 \mathrm{bp}$}
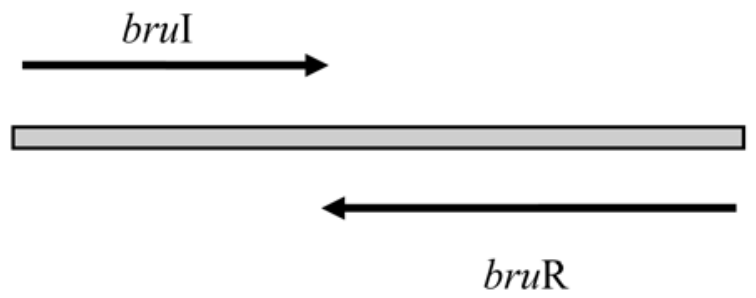

$735 \mathrm{bp}$

Fig. 7. Genetic locus containing bruI and bruR genes in Brenneria rubrifaciens $6 \mathrm{D} 370$. Orientation of bruI and bruR open reading frames in B. rubrifaciens $6 \mathrm{D} 370$ depicted to scale using vector NTI software. National Center for Biotechnology Information accession number bruI-bruR locus: FJ167366.
The $b r u \mathrm{I}-b r u \mathrm{R}$ locus described here is the first description of a luxI-luxR pair described for any Brenneria spp. The production of the same structural AHLs, 30C6HSL and C6HSL, by B. nigrifluens, B. salicis, and $B$. rubrifaciens and the induction of rubrifacine in $\mathrm{Br}-212$ with $B$. salicis and $B$. nigrifluens extracts suggest that $l u x \mathrm{I}$ homologs are present in both species. In addition, mutant $\mathrm{Br}-212$ will be useful as a new pigment-based bioreporter strain for short-chain AHLs. Understanding the role of $\mathrm{QS}$ in $B$. rubrifaciens is a prerequisite for understanding $\mathrm{DBC}$ and may provide insights into the long latency period of this disease, which has been poorly understood for decades.

\section{ACKNOWLEDGMENTS}

This work was supported in part by the United States Department of Agriculture (USDA)-Agricultural Research Service CRIS project number 5306-22000-014-00D, a grant from the California Walnut Board, and the National Institute of General Medical Sciences (NRSA T32 GM07270). USDA is an equal opportunity provider and employer. We thank C. Roper (University of California [UC], Riverside) for providing the Chromobacterium violaceum CV026 reporter strain and C. Holsclaw (UC Davis Campus Mass Spectrometry Facilities) for technical assistance for LCMS analyses.

\section{LITERATURE CITED}

1. Alfano, J. R., and Collmer, A. 1997. The type III (Hrp) secretion pathway of plant pathogenic bacteria: Trafficking harpins, Avr proteins, and death. J. Bacteriol. 179:5655-5662.

2. Al-Ghonaiem, M. I., Ibrahim, A. S. S., and Al-Salamah, A. A. 2009. Swimming motility in Agrobacterium tumefaciens is controlled by quorum sensing and inhibited by garlic bulb extract. Res. J. Microbiol. 4:345-354.

3. Altschul, S. F., Gish, W., Miller, W., Myers, E. W., and Lipman, D. J. 1990. Basic local alignment search tool. J. Mol. Biol. 215:403-410.

4. Antunes, L. C. M., Ferreira, R. B. R., Lostroh, C. P., and Greenberg, E. P. 2008. A mutational analysis defines Vibrio fischeri LuxR binding sites. J. Bacteriol. 190:4392-4397.

5. Atkinson, S., and Williams, P. 2009. Quorum sensing and social networking in the microbial world. J. R. Soc. Interface 6:959-978.

6. Azad, H. R., and Kado, C. I. 1980. Numerical and DNA-DNA reassociation analyses of Erwinia rubrifaciens and other members of the Enterobacteriaceae. J. Gen. Microbiol. 120:117-129.

7. Badri, D. V., Weir, T. L., van der Lelie, D., and Vivanco, J. M. 2009. Rhizosphere chemical dialogues: Plant-microbe interactions. Curr. Opin. Biotechnol. 20:642-650.

8. Barnard, A. M. L., Bowden, S. D., Burr, T., Coulthurst, S. J., Monson, R. E., and Salmond, G. P. C. 2007. Quorum sensing, virulence and secondary metabolite production in plant soft-rotting bacteria. Philos. Trans. R. Soc. Lond. B Biol. 362:1165-1183.

9. Barny, M. A. 1995. Erwinia amylovora hrpN mutants, blocked in harpin synthesis, express a reduced virulence on host plants and elicit variable hypersensitive reactions on tobacco. Eur. J. Plant Pathol.101:333-340.

10. Bassler, B. L. 1999. How bacteria talk to each other: Regulation of gene expression by quorum sensing. Curr. Opin. Microbiol.2:582-587.

11. Bassler, B. L. 2002. Small talk: Cell-to-cell communication in bacteria. Cell 109:421-424.

12. Bauer, D. W., Bogdanove, A. J., Beer, S. V., and Collmer, A. 1994. Erwinia chrysanthemi hrp genes and their involvement in soft-rot pathogenesis and elicitation of the hypersensitive response. Mol. Plant-Microbe Interact. 7:573-581.

13. Berg, G., Eberl, L., and Hartmann, A. 2005. The rhizosphere as a reservoir for opportunistic human pathogenic bacteria. Environ. Microbiol. 7:1673-1685.

14. Boyer, M., and Wisniewski-Dyé, F. 2009. Cell-cell signalling in bacteria: Not simply a matter of quorum. FEMS Microbiol. Ecol. 70:1-19.

15. Büttner, D., and He, S. Y. 2009. Type III protein secretion in plant pathogenic bacteria. Plant Physiol. 150:1656-1664.

16. Choi, S. H., and Greenberg, E. P. 1992. Genetic evidence for multimerization of LuxR, the transcriptional activator of Vibrio fischeri luminescence. Mol. Mar. Biol. Biotechnol. 1:408-413.

17. Choi, S. H., and Greenberg, E. P. 1992. Genetic dissection of DNA binding and luminescence gene activation by the Vibrio fischeri LuxR protein. J. Bacteriol. 174:4064-4069.

18. Chugani, S. A., Whiteley, M., Lee, K. M., D’Argenio, D., Manoil, C., and Greenberg, E. P. 2001. QscR, a modulator of quorum-sensing signal 
synthesis and virulence in Pseudomonas aeruginosa. Proc. Natl. Acad. Sci. USA 98:2752-2757.

19. Clowers, B. H., Dodds, E. D., Seipert, R. R., and Lebrilla, C. B. 2008. Dual polarity accurate mass calibration for electrospray ionization and matrix-assisted laser desorption/ionization mass spectrometry using maltooligosaccharides. Anal. Biochem. 381:205-213.

20. Delmont, T. O., Robe, P., Cecillon, S., Clark, I. M., Constancias, F., Simonet, P., Hirsch, P. R., and Vogel, T. M. 2011. Accessing the soil metagenome for studies of microbial diversity. Appl. Environ. Microbiol. 77:1315-1324.

21. Duerkop, B. A., Varga, J., Chandler, J. R., Peterson, S. B., Herman, J. P., Churchill, M. E. A., Parsek, M. R., Nierman, W. C., and Greenberg, E. P. 2009. Quorum-sensing control of antibiotic synthesis in Burkholderia thailandensis. J. Bacteriol. 191:3909-3918.

22. Eberhard, A., Burlingame, A. L., Eberhard, C., Kenyon, G. L., Nealson, K. H., and Oppenheimer, N. J. 1981. Structural identification of autoinducer of Photobacterium fischeri luciferase. Biochemistry 20:24442449.

23. Eberl, L., Winson, M. K., Sternberg, C., Stewart, G. S., Christiansen, G., Chhabra, S. R., Bycroft, B., Williams, P., Molin, S., and Givskov, M. 1996. Involvement of N-acyl-L-hormoserine lactone autoinducers in controlling the multicellular behaviour of Serratia liquefaciens. Mol. Microbiol. 20:127-36.

24. Engebrecht, J., and Silverman, M. 1984. Identification of genes and gene products necessary for bacterial bioluminescence. Proc. Natl. Acad. Sci. USA 81:4154-4158.

25. Feistner, G., and Budzikiewicz, H. 1985. The structure of rubrifacine. Can. J. Chem. 63:495-499.

26. Feistner, G., Korth, H., Ko, H., Pulverer, G., and Budzikiewicz, H. 1983. Ferrorosamine A from Erwinia rhapontici. Curr. Microbiol. 8:239-243.

27. Filteau, M., Lagacé, L., LaPointe, G., and Roy, D. 2010. Seasonal and regional diversity of maple sap microbiota revealed using community PCR fingerprinting and $16 \mathrm{~S}$ rRNA gene clone libraries. Syst. Appl. Microbiol. 33:165-173.

28. Fuqua, C., and Greenberg, E. P. 2002. Listening in on bacteria: Acylhomoserine lactone signalling. Nat. Rev. Mol. Cell. Biol. 3:685-695.

29. Fuqua, W. C., Winans, S. C., and Greenberg, E. P. 1994. Quorum sensing in bacteria: The LuxR-LuxI family of cell density-responsive transcriptional regulators. J. Bacteriol. 176:269-275.

30. Gao, M., Teplitski, M., Robinson, J. B., and Bauer, W. D. 2003. Production of substances by Medicago truncatula that affect bacterial quorum sensing. Mol. Plant-Microbe Interact. 16:827-834.

31. Huvenne, H., Goeminne, G., Maes, M., and Messens, E. 2008. Identification of quorum sensing signal molecules and oligolignols associated with watermark disease in willow (Salix sp.). J. Chromatogr. B 872:83-89.

32. Kado, C. I., Dutra, J. C., Moller, W. J., and Ramos, D. E. 1977. An assessment of the susceptibility of various walnut cultivars to deep bark canker. J. Am. Soc. Hortic. Sci. 102:698-702.

33. Keith, K. E., Killip, L., He, P., Moran, G. R., and Valvano, M. A. 2007. Burkholderia cenocepacia C5424 produces a pigment with antioxidant properties using a homogentisate intermediate. J. Bacteriol. 189:90579065.

34. Klement, Z., and Goodman, R. N. 1967. The hypersensitive reaction to infection by bacterial plant pathogens. Annu. Rev. Phytopathol. 5:17-44.

35. Kuo, A., Blough, N. V., and Dunlap, P. V. 1994. Multiple N-acyl-Lhomoserine lactone autoinducers of luminescence in the marine symbiotic bacterium Vibrio fischeri. J. Bacteriol. 176:7558-7565.

36. Liu, H., Coulthurst, S. J., Pritchard, L., Hedley, P. E., Ravensdale, M., Humphris, S., Burr, T., Takle, G., Brurberg, M.-B., Birch, P. R. J., Salmond, G. P. C., and Toth, I. K. 2008. Quorum sensing coordinates brute force and stealth modes of infection in the plant pathogen Pectobacterium atrosepticum. PLoS Pathog. 4:e1000093.

37. Loreti, S., Galleli, A., Piccirillo, P., and Belisario, A. 2005. Bacterial bark canker on English walnut. Acta Hortic. 705:433-435.

38. Maes, M., Baeyen, S., De Croo, H., De Smet, K., and Steenackers, M. 2002. Monitoring of endophytic Brenneria salicis in willow and its relation to watermark disease. . Plant Prot. Sci. 38:528-530.

39. Maes, M., Huvenne, H., and Messens, E. 2009. Brenneria salicis, the bacterium causing watermark disease in willow, resides as an endophyte in wood. Environ. Microbiol. 11:1453-1462.

40. Malott, R. J., O'Grady, E. P., Toller, J., Inhulsen, S., Eberl, L., and Sokol, P. A. 2009. A Burkholderia cenocepacia orphan LuxR homolog is involved in quorum-sensing regulation. J. Bacteriol. 191:2447-2460.

41. Martinelli, D., Grossmann, G., Sequin, U., Brandl, H., and Bachofen, R. 2004. Effects of natural and chemically synthesized furanones on quorum sensing in Chromobacterium violaceum. BMC Microbiol. 4. doi:10.1186/ 1471-2180-4-25.

42. McClean, A. E., and Kluepfel, D. A. 2009. Genetic loci involved in rubrifacine production in the walnut pathogen Brenneria rubrifaciens.
Phytopathology 99:145-151.

43. McClean, K. H., Winson, M. K., Fish, L., Taylor, A., Chhabra, S. R., Camara, M., Daykin, M., Lamb, J. H., Swift, S., Bycroft, B. W., Stewart, G. S. A. B., and Williams, P. 1997. Quorum sensing and Chromobacterium violaceum: Exploitation of violacein production and inhibition for the detection of $\mathrm{N}$-acylhomoserine lactones. Microbiology 143:37033711 .

44. Nasser, W., Bouillant, M., Salmond, G., and Reverchon, S. 1996. Characterization of the Erwinia chrysanthemi exp I-exp $R$ locus directing the synthesis of two $\mathrm{N}$-acyl homoserine lactone signal molecules. Mol. Microbiol. 29:1391-1405.

45. Pacheco, A. R., and Sperandio, V. 2009. Inter-kingdom signaling: Chemical language between bacteria and host. Curr. Opin. Microbiol. 12:192-198.

46. Parsek, M. R., and Greenberg, E. P. 2005. Sociomicrobiology: The connections between quorum sensing and biofilms. Trends Microbiol. 13:27-33.

47. Pirhonen, M., Flego, D., Heikinheimo, R., and Palva, E. T. 1993. A small diffusible signal molecule is responsible for the global control of virulence and exoenzyme production in the plant pathogen Erwinia carotovora. EMBO J. 12:2467-2476.

48. Rasmussen, T. B., Skindersoe, M. E., Bjarnsholt, T., Phipps, R. K., Christensen, K. B., Jensen, P. O., Andersen, J. B., Koch, B., Larsen, T. O., Hentzer, M., Eberl, L., Hoiby, N., and Givskov, M. 2005. Identity and effects of quorum-sensing inhibitors produced by Penicillium species. Microbiology (Read.) 151:1325-1340.

49. Reading, N. C., and Sperandio, V. 2006. Quorum sensing: The many languages of bacteria. FEMS Microbiol. Lett. 254:1-11.

50. Reverchon, S., Rouanet, C., Expert, D., and Nasser, W. 2002. Characterization of indigoidine biosynthetic genes in Erwinia chrysanthemi and role of this blue pigment in pathogenicity. J. Bacteriol. 184:654-665.

51. Riedel, K., Hentzer, M., Geisenberger, O., Huber, B., Steidle, A., Wu, H., Hoiby, N., Givskov, M., Molin, S., and Eberl, L. 2001. N-Acylhomoserinelactone-mediated communication between Pseudomonas aeruginosa and Burkholderia cepacia in mixed biofilms. Microbiology 147:3249-3262.

52. Saccardi, A., Bonetti, V., Melegatti, A., and Cristanini, M. 1998. Occurrence of Erwinia nigrifluens on English walnut (Juglans regia) in the Veneto Region (northern Italy). J. Plant Pathol. 80:63-65.

53. Schaad, N. W., and Wilson, E. E. 1971. The ecology of Erwinia rubrifaciens and the development of phloem canker of Persian walnut. Annu. Appl. Biol. 69:125-136.

54. Schaefer, A. L., Val, D. L., Hanzelka, B. L., Cronan, J. E., and Greenberg, E. P. 1996. Generation of cell-to-cell signals in quorum sensing: Acyl homoserine lactone synthase activity of a purified Vibrio fischeri LuxI protein. Proc. Natl. Acad. Sci. USA 93:9505-9509.

55. Shaw, P. D., Ping, G., Daly, S. L., Cha, C., Cronan, J. E., Rinehart, K. L., and Farrand, S. K. 1997. Detecting and characterizing N-acyl-homoserine lactone signal molecules by thin-layer chromatography. Proc. Natl. Acad. Sci. USA 94:6036-6041

56. Song, Y., Xie, C., Ong, Y.-M., Gan, Y.-H., and Chua, K.-L. 2005. The BpsIR Quorum-Sensing System of Burkholderia pseudomallei. J. Bacteriol. 187:785-790.

57. Stevens, A. M., and Greenberg, E. P. 1999. Transcriptional activation by LuxR. InL Cell-Cell Signaling in Bacteria. G. M. Dunny and S. C. Winans, eds. American Society for Microbiology Press, Washington, DC.

58. Sun, L., Qiu, F., Zhang, X., Dai, X., Dong, X., and Song, W. 2008. Endophytic bacterial diversity in rice (Oryza sativa $\mathrm{L}$.) roots estimated by 16S rDNA sequence analysis. Microb. Ecol. 55:415-424.

59. Teplitski, M., Chen, H., Rajamani, S., Gao, M., Merighi, M., Sayre, R. T., Robinson, J. B., Rolfe, B. G., and Bauer, W. D. 2004. Chlamydomonas reinhardtii secretes compounds that mimic bacterial signals and interfere with quorum sensing regulation in bacteria. Plant Physiol. 134:137-146.

60. Teplitski, M., Eberhard, A., Gronquist, M. R., Gao, M., Robinson, J. B., and Bauer, W. D. 2003. Chemical identification of N-acyl homoserine lactone quorum-sensing signals produced by Sinorhizobium meliloti strains in defined medium. Arch. Microbiol. 180:494-497.

61. Teplitski, M. M., Gao, M., and Robinson, J. 2011. Integration of cell-tocell signals in soil bacterial communities. In: Biocommunication in Soil Microorganisms, Soil Biology. G. Witzany, eds. Springer, Berlin Heidelberg, Germany.

62. Teviotdale, B. L., and Sibbett, G. S. 1982. Midwinter irrigation can reduce deep bark canker of walnuts. Calif. Agric. 36:6-7.

63. Teviotdale, B. L., Sibbett, G. S., Fitch, L., and Harper, D. H. 1991. Budwood transmission of Erwinia rubrifaciens, causal agent of deep bark canker disease of English walnut. Plant Dis. 75:360-363.

64. Vandeputte, O. M., Kiendrebeogo, M., Rajaonson, S., Diallo, B., Mol, A., El Jaziri, M., and Baucher, M. 2011. Identification of catechin as one of the flavonoids from Combretum albiflorum bark extract that reduces the production of quorum-sensing-controlled virulence factors in Pseudoonas aeruginosa PAO1. Appl. Environ. Microbiol. 76:243-253. 
65. Vendeville, A., Winzer, K., Heurlier, K., Tang, C. M., and Hardie, K. R. 2005. Making "sense" of metabolism: Autoinducer-2, LUXS and pathogenic bacteria. Nat. Rev. Microbiol. 3:383-396.

66. Venturi, V., and Subramoni, S. 2009. Future research trends in the major chemical language of bacteria. HFSP J. 3:105-116.

67. von Bodman, S. B., Bauer, W. D., and Coplin, D. L. 2003. Quorum sensing in plant-pathogenic bacteria Annu. Rev. Phytopathol. 41:455-482.

68. Waters, C. M., and Bassler, B. L. 2005. Quorum sensing: Cell-to-cell communication in bacteria. Annu. Rev. Cell Dev. Biol. 21:319-346.

69. Whitehead, N. A., Barnard, A. M. L., Slater, H., Simpson, N. J. L., and Salmond, G. P. C. 2001. Quorum-sensing in gram-negative bacteria. FEMS Microbiol. Rev. 25:365-404.
70. Wilson, E. E., Starr, M. P., and Berger, J. A. 1957. Bark canker, a bacterial disease of the Persian walnut tree. Phytopathology 47:669-673.

71. Wilson, E. E., Zeitoun, F., and Fredrickson, D. L. 1967. Bacterial phloem canker, a new disease of Persian walnut trees. Phytopathology 57:618621.

72. Winson, M. K., Camara, M., Latifi, A., Foglino, M., Chhabra, S. R., Daykin, M., Bally, M., Chapon, V., Salmond, G. P., and Bycroft, B. W. 1995. Multiple N-acyl-L-homoserine lactone signal molecules regulate production of virulence determinants and secondary metabolites in Pseudomonas aeruginosa. Proc. Natl. Acad. Sci. USA 92:9427-9431.

73. Wisniewski-Dyé, F., and Downie, J. 2002. Quorum-sensing in Rhizobium. Antonie Leeuwenhoek 81:397-407. 